\title{
Prevention Strategies for Reproductive Disorders in Female Teenager in the Islamic Boarding School Bahrul Ulum DU SKPC
}

\author{
Yuyun Bewelli Fahmi ${ }^{1}$, Andriana ${ }^{2}$, Elvira Junita ${ }^{3}$, Diana Indah Permata Sari ${ }^{4}$ \\ Prodi D III Kebidanan Universitas Pasir Pengaraian \\ Email andriana.midw@gmail.com
}

Article Info

Article history

Received date: 2019-10-24

Revised date: 2019-11-29

Accepted date: 2019-12-13

\begin{abstract}
Personal hygiene during menstruation is an action to maintain health and hygiene in the female area during menstruation. If during menstruation does not maintain good hygiene there is a risk of reproductive infections. This is caused by menstrual events that bleed. During menstruation, blood vessels in the uterus are very susceptible to infection because blood and sweat coming out and sticking to the vulva can cause genetal areas to become moist. Various reproductive disorders that occur due to infection with germ during menstruation include Reproductive Tract Infection (ISR), Bacterial Vaginosis (BV) infection, Urinary Tract Infection (UTI), reproductive tract infections if treated immediately can lead to malignancy, and preterm birth and birth weight low in pregnant women. To prevent problems with the reproductive organs, it is necessary to pay attention to menstrual hygiene. One of the efforts that can be done to prevent disorders of the reproductive system in women by increasing the knowledge and awareness of young women early on about personal hygiene during menstruation through health education and health education. The purpose of this study is to determine strategies to prevent reproductive disorders in young women in Islamic boarding schools. Bahrul Ulum Kec. Browse Kab. Rohul. This type of research is quantitative analytic with the research design used is a pre-experiment with a post-test pre-test approach. The research sample was conducted on 50 respondents. The results of data analysis with the dependent $T$ test found that counseling about personal hygiene significantly affected the behavior of adolescent girls during menstruation with a value of $p=0.001$. It is recommended to conduct counseling about personal hygiene during menstruation so that it can be used as one of the strategies in preventing reproductive health disorders
\end{abstract}

Keywords:

counseling, personal hygiene, menstruation, behavior

\section{Abstrak}

Personal hygiene saat menstruasi adalah tindakan untuk memelihara kesehatan dan kebersihan pada daerah kewanitaan pada saat menstruasi. Bila saat menstruasi tidak menjaga kebersihan yang baik akan berisiko mengalami infeksi alat reproduksi. Hal ini disebabkan oleh peristiwa menstruasi yang mengeluarkan darah kotor. Pada saat menstruasi, pembuluh darah dalam rahim sangat mudah terkena infeksi karena darah dan keringat keluar serta menempel pada vulva dapat menyebabkan daerah genetalia menjadi lembab. Berbagai ganguan reproduksi yang teriadi akibat terinfeksi kuman saat menstruasi antara lain Infeksi Saluran Reproduksi (ISR), infeksi Bacterial Vaginosis (BV), Infeksi Saluran Kemih (ISK), infeksi saluran reproduksi jika diatasi segera dapat menimbulkan keganasan, dan kelahiran preterm serta berat badan lahir rendah pada wanita hamil. Untuk mencegah terjadinya permasalahan pada organ reproduksi maka perlu memperhatikan hygiene menstruasi. Salah satu upaya yang dapat dilakukan untuk mencegah gangguan sistem reproduksi pada wanita dengan meningkatkan pengetahuan dan kesadaran remaja putri sejak dini tentang personal hygiene saat menstruasi melalui penyuluhan kesehatan dan pendidikan kesehatan.Tujuan penelitian ini adalah untuk mengetahui strategi pencegahan gangguan reproduksi pada remaja putri di Pondok Pesantren Bahrul Ulum Kec. Rambah Kab. Rohul. Jenis penelitian ini adalah kuantitatif analitik dengan rancangan penelitian yang digunakan adalah praeksperimen 
dengan pendekatan pre-test post-test. Sampel penelitian ini dilakukan pada 50 responden. Hasil analisa data dengan uji $T$ dependen diketahui bahwa penyuluhan tentang personal hygiene berpengaruh secara signifikan terhadap perilaku remaja putri pada saat menstruasi dengan nilai $p=0,001$. Disarankan untuk melakukan penyuluhan tentang personal hygiene saat menstruasi sehingga dapat dijadikan salah satu strategi dalam mencegah gangguan kesehatan reproduksi

\section{Kata Kunci}

penyuluhan, personal Hygiene, menstruasi, perilaku

\section{PENDAHULUAN}

Perilaku merupakan respon atau reaksi seseorang terhadap stimulus (rangsangan dari luar). Secara teori perubahan perilaku atau seseorang menerima atau mengadopsi perilaku baru dalam kehidupannya melalui 3 tahap yaitu pengetahuan, sikap dan tindakan /praktik (1).

Personal hygiene saat menstruasi adalah tindakan untuk memelihara kesehatan dan kebersihan pada daerah kewanitaan pada saat menstruasi (2). Bila saat menstruasi tidak menjaga kebersihan yang baik akan berisiko mengalami infeksi alat reproduksi. Hal ini disebabkan oleh peristiwa menstruasi yang mengeluarkan darah kotor. Pada saat menstruasi, pembuluh darah dalam rahim sangat mudah terkena infeksi karena darah dan keringat keluar serta menempel pada vulva dapat menyebabkan daerah genetalia menjadi lembab. Jika pada saat itu tidak menjaga kebersihan genetalia dengan benar, maka dalam keadaan lembab, jamur dan bakteri yang berada di daerah genetalia akan tumbuh subur sehingga menyebabkan rasa gatal dan infeksi pada daerah tersebut. Salah satu keluhan yang dirasakan pada menstruasi adalah rasa gatal yang disebabkan oleh jamur kandida yang akan subur tumbuhnya pada saat haid serta dapat menyebabkan keputihan yang bisa disebabkan karena pemakaian pantyliner yang tidak berkesinambungan (3).

Masa remaja adalah masa transisi yang ditandai oleh adanya perubahan fisik, emosi dan psikis. Masa remaja, yakni antara usia 10 - 19 tahun, masa remaja adalah suatu periode masa pematangan organ reproduksi manusia, dan sering disebut masa pubertas, bisa juga dikatakan masa peralihan dari masa kanak - kanak ke masa dewasa (4).

Kesehatan reproduksi remaja adalah suatu kondisi sehat yang menyangkut sistem, fungsi, dan proses reproduksi yang dimiliki oleh remaja. Pengertian sehat disini tidak semata-mata berarti bebas penyakit atau bebas dari kecacatan namun juga sehat secara mental serta sosial kultural (1).

Berbagai permasalahan yang terjadi akibat terinfeksi kuman saat menstruasi antara lain Infeksi Saluran Reproduksi (ISR), infeksi Bacterial Vaginosis (BV), Infeksi Saluran Kemih (ISK), dan kelahiran preterm serta berat badan lahir rendah pada wanita hamil. Untuk mencegah terjadinya permasalahan pada organ reproduksi maka perlu memperhatikan higiene menstruasi (5)

Saat ini, banyak remaja yang kurang mendapatkan penerangan mengenai kesehatan reproduksi. Salah satu masalah yang menonjol dikalangan remaja yaitu permasalahan kesehatan reproduksi remaja (6). Remaja perlu pendampingan agar tidak menerima informasi yang salah, yang dapat berdampak pada kesehatan seksual dan reproduksinya terutama infeksi organ reproduksi khususnya pada remaja perempuan karena lebih rentan terkena dibandingkan dengan pria (7).

Data yang diperoleh dari Dinas Kesehatan Rokan Hulu, jumlah remaja putri Mts sebanyak 4277 siswi. Data yang diperoleh dari Pondok Pesantren Al-Madani Islamic Centre berjumlah 76 siswi dan di Pondok Pesantren Istek berjumlah 75 siswi, 
sedangkan jumlah siswi di Pondok Pesantren Bahrul Ulum sebanyak 50 siswi.

Berdasarkan studi pendahuluan yang telah dilakukan di Pondok Pesantren Bahrul Ulum pada tanggal 17 Oktober 2018, informasi dari bagian bimbingan dan konseling di Pondok Pesantren Bahrul Ulum mengatakan bahwa pembelajaran kesehatan reproduksi sudah dijadwalkan tetapi untuk pelaksanaan programnya belum dapat dilakukan secara teratur karena keterbatasan tenaga kesehatan. Materi yang diberikan hanya secara umum mengenai kesehatan reproduksi remaja untuk cara merawat organ kewanitaan atau organ reproduksi yang dimiliki belum dilakukan.

Wawancara yang dilakukan di Pondok Pesantren Bahrul Ulum pada 10 orang siswi yang telah menstruasi, 5 orang siswi sudah mengetahui cara melakukan personl hygiene yang benar saat menstruasi. Kurangnya pengetahuan siswi di karenakan jauh dari kota dan kurangnya informasi tentang personal hygiene dan jauhnya pelayanan kesehatan. Dari hasil studi pendahuluan yang telah dilakukan maka peneliti tertarik untuk mengadakan penelitian dengan judul "Strategi pencegahan gangguan reproduksi Pada Remaja Putri Di Pondok Pesantren Bahrul Ulum DU SKPC".

Berdasarkan uraian dalam latar belakang masalah di atas, dapat dirumuskan pertanyaan penelitian sebagai berikut: Apakah Penyuluhan Tentang Personal Hygiene berpengaruh Terhadap Perilaku Personal Hygiene Saat Menstruasi pada Siswi Pondok Pesantren Bahrul Ulum DU SKPC ?

\section{METODE}

Jenis penelitian ini adalah kuantitatif analitik dengan Rancangan penelitian yang digunakan adalah Praeksperimen dengan pendekatan pre - test post - test. Untuk melihat apakah ada pengaruh pemberian penyuluhan terhadap perilaku personal hygiene saat menstruasi pada siswi di Pondok Pesantren Bahrul Ulum DU SKPC.

Skema Rancangan Penelitian

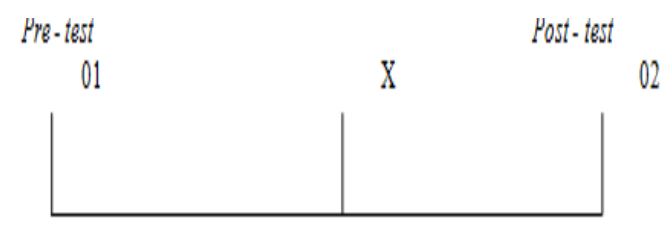

Sumber: (Notoatmodjo, 2010)

Dari gambar diatas dijelaskan bahwa:

01 : Pemantauan perilku pertama pada remaja

$X$ : Perlakuan dengan pemberian penyuluhan personal hygiene saat menstruasi pada remaja

02: Pengaruh pemberian penyuluhan apakah terjadi perubahan perilaku

Teknik pengambilan sampel menggunakan sampling jenuh yaitu teknik pengambilan sampel bila semua anggota populasi digunakan sebagai sampel sebanyak 50 orang. Pengumpulan data dengan menggunakan kuesioner. Analisis data terdiri dari analisis univariat dan analisis bivariat dengan uji T-Test dependen sebagai penguji hipotesis.

\section{HASIL DAN PEMBAHASAN}

\section{Analisis Univariat}

Berdasarkan penelitian yang telah dilakukan peneliti tentang Pengaruh Penyuluhan Tentang Personal Hygiene Terhadap Perilaku Personal Hygiene Saat Menstruasi Pada Remaja Putri Di Pondok Pesantren Bahrul Ulum DU SKPC dengan jumlah responden 50 remaja dengan menggunakan analisis univariat di dapat hasil pada tabel dibawah ini: 
Tabel 1. Distribusi Frekuensi Perilaku pada Remaja Putri Di Pondok Pesantren Bahrul Ulum Sebelum (pre-test) dan sesudah (pos-test) dilakukan Penyuluhan

\begin{tabular}{ccccc}
\hline \multirow{2}{*}{ Perilaku } & \multicolumn{2}{c}{ Sebelum } & \multicolumn{2}{c}{ Sesudah } \\
\cline { 2 - 5 } & Frekuensi & $\%$ & Frekuensi & $\%$ \\
\hline Baik & 26 & 52 & 37 & 74 \\
\hline Buruk & 24 & 48 & 13 & 26 \\
\hline Jumlah & 50 & 100 & 50 & 100 \\
\hline
\end{tabular}

Sumber : Data Primer

Dari tabel menunjukkan bahwa dari 50 responden yang diteliti terjadi peningkatan perilaku remaja putri yaitu dari 26 (52\%) responden yang tindakannya baik meningkat menjadi $37(74 \%)$ responden yang tindakannya baik, sedangkan yang memiliki tindakan buruk menurun dari $24(48 \%)$ responden berkurang menjadi $13(26 \%)$ responden tindakan yang buruk.

\section{Analisa Bivariat}

Tabel 2 Pengaruh Penyuluhan terhadap Perilaku pada Remaja Putri di Pondok Pesantren Bahrul Ulum menurut pengukuran sebelum diberikan penyuluhan (pre-test) dan setelah diberikan penyuluhan (post-test)

\begin{tabular}{|c|c|c|c|c|c|c|}
\hline & Variabel & Mean & SD & SE & $\begin{array}{c}\mathrm{P} \\
\text { Value }\end{array}$ & $\mathrm{N}$ \\
\hline & Perilaku & & & & & \\
\hline & Pre - test & 25,62 & 3,522 & 0,498 & 0,001 & 50 \\
\hline umber : Data & Post - test & 32,04 & 1,714 & 0,242 & & \\
\hline
\end{tabular}

Rata-rata perilaku sebelum diberikan penyuluhan adalah 25,62 dengan standar deviasi 3,522. Pada perilaku setelah dilakukan penyuluhan didapat rata rata 32,04 dengan standar deviasi 1,714 . Terlihat nilai mean perbedaan antara perilaku sebelum diberikan penyuluhan dan sesudah diberikan penyuluhan adalah 6,420 dengan standar deviasi 4,238. Hasil Rata-rata perilaku sebelum diberikan penyuluhan adalah 25,6 dengan standar deviasi 3,5. Pada perilaku setelah dilakukan penyuluhan didapat rata rata 32,0 dengan standar deviasi 1,7. Terlihat nilai mean perbedaan antara perilaku sebelum diberikan penyuluhan dan sesudah diberikan penyuluhan adalah 6,4 dengan standar deviasi 4,2. Hasil uji statistik didapatkan nilai $\rho=0,001$ maka dapat disimpulkan ada perbedaan yang signifikan antara perilaku sebelum diberikan penyuluhan dan sesudah diberikan penyuluhan uji statistik didapatkan nilai $\rho=0,001$ maka dapat disimpulkan ada perbedaan yang signifikan antara perilaku sebelum diberikan penyuluhan dan sesudah diberikan penyuluhan.

\section{Pembahasan}

Rata-rata perilaku sebelum diberikan penyuluhan adalah 25,6 dengan standar deviasi 3,5. Pada perilaku setelah dilakukan penyuluhan didapat rata rata 32,0 dengan standar deviasi 1,7. Terlihat nilai mean perbedaan antara perilaku sebelum diberikan penyuluhan dan sesudah diberikan penyuluhan adalah 6,4 dengan standar deviasi 4,2. Hasil uji statistik didapatkan nilai $\rho=0,001$ maka dapat disimpulkan ada perbedaan yang signifikan antara perilaku sebelum 
diberikan penyuluhan dan sesudah diberikan penyuluhan

Adanya perubahan perilaku responden terhadap perilaku personal hygiene responden yang telah diberikan penyuluhan memberikan indikasi bahwa responden memiliki kesadaran yang baik untuk menghindari dampak negatif dari perilaku personal hygiene yang cukup ataupun buruk. Penyuluhan ini merupakan upaya preventif untuk menuju reproduksi sehat yang dimulai pada usia remaja. Remaja ini dipersiapkan untuk mencapai reproduksi yang sehat (8).

Responden yang menunjukkan perilaku cukup terhadap personal hygiene, memberikan indikasi bahwa ada kemungkinan responden telah melakukan perilaku personal hygiene yang tidak benar. Responden yang menunjukkan perilaku cukup terhadap personal hygiene yang dapat disebabkan karena belum mengetahui dampak yang ditimbulkan dari perilaku personal hygiene yang tidak benar. Responden yang belum mengetahui tentang personal hygiene yang benar memungkinkan untuk berperilaku cukup dalam hal mendukung terwujudnya menjadi perilaku kurang baik pada personal hygiene.

Remaja perempuan dianjurkan untuk selalu berperilaku sehat karena lebih mudah terkena infeksi genital apabila tidak menjaga kebersihan alat genitalnya karena organ vagina yang letaknya berdekatan dengan anus. Perilaku yang buruk dalam menjaga organ genitalia akan memberikan efek negatif pada kesehatan repoduksinya (9).

Hasil post-test menunjukkan dengan adanya intervensi yang diberikan dapat memberikan perubahan perilaku personal hygien saat menstruasi. Dari intervensi yang diberikan para remaja putri tersebut menjadi tahu manfaat dan tujuan personal hygiene yang benar. Peningkatan pengetahuan tersebut berdampak positif pada perbaikan perilaku remaja putri dalam menjaga alat reproduksinya.
Hasil penelitian ini sesuai dengan penelitian yang dilakukan oleh Widyaningrum tahun 2015, bahwa ada pengaruh penyuluhan tentang personal hygiene terhadap perilaku personal hygiene saat menstruasi di MTS Negeri Gubuk Rubuh Yogyakarta (10).

Psikologi memandang perilaku manusia sebagai reaksi yang dapat bersifat sederhana maupun kompleks. Perilaku dapat diartikan sebagai suatu respon organisme atau seseorang terhadap rangsangan (stimulus) dari luar subjek yang dapat berbentuk respon internal yang tidak dapat dilihat seperti pengetahuan dan sikap serta respon eksternal yang dapat dilihat seperti tindakan. Dari segi biologis, perilaku adalah suatu kegiatan atau aktivitas makhluk hidup yang bersangkutan. Sehingga dapat disimpulkan yang dimaksud perilaku (manusia) adalah semua kegiatan atau aktivitas manusia, baik yang dapat diamati langsung, maupun yang tidak dapat diamati oleh pihak luar (11).

Teori dan hasil penelitian terdahulu mendukung hasil penelitian ini, bahwa pengetahuan, sikap dan tindakan yang baik kemungkinan besar akan memberikan pandangan seseorang untuk berperilaku baik pula, sehingga dalam hal ini lebih meminimalkan kemungkinan terjadinya infeksi saluran reproduksi (ISR) ataupun penyakit reproduksi lainnya $(12,13)$.

Penyuluhan merupakan salah satu cara untuk menyampaikan informasi dengan cepat kepada banyak orang. Pentingnya penyuluhan merupakan cara yang praktis dan simple dalam menyampaikan informasi kepada orang lain dimana merupakan sebuah system pendidikan informal $(14,15)$.

Peneliti berasumsi bahwa dengan adanya penyuluhan tentang personal hygiene ini dapat meningkatkan dan merubah perilaku remaja putri dari yang tidak tahu menjadi tahu dan dari yang mempunyai sikap maupun tindakan buruk terhadap 
personal hygiene saat menstruasi menjadi berperilaku baik.
Pengelolaan Pusat Informasi Dan Konseling Remaja Dan Mahasiswa (Pik Remaja/Mahasiswa)". Jakarta: BKKBN, 2012

\section{SIMPULAN}

Penyuluhan tentang personal hygiene dapat merubah perilaku remaja putri dari yang tidak tahu menjadi tahu dan dari yang mempunyai sikap maupun tindakan buruk terhadap personal hygiene saat menstruasi menjadi berperilaku baik, sehingga dapat dijadikan salah satu strategi dalam mencegah gangguan kesehatan reproduksi.

\section{UCAPAN TERIMA KASIH}

Peneliti mengucapkan terimakasih kepada LPPM Universitas Pasir Pengaraian yang telah mendukung terlaksananya penelitian ini dan khususnya kepada TIM peneliti.

\section{DAFTAR PUSTAKA}

[1] Irianto, K. "Kesehatan Reproduksi". Bandung: Alfabeta, 2015

[2] Laily dan Sulistyo. "Personal Hygiene Konsep, Proses dan Aplikasi Dalam praktik Keperawatan". Yogyakarta: Graha llmu, 2012

[3] Andira, D. "Seluk Beluk Kesehatan Reproduksi Wanita". Yogyakarta: APluss. Books, 2010

[4] Widyastuti, Y., Rahmawati, A., \& Purnamaningrum, E. Y. "kesehatan reproduksi". Yogyakarta: Fitramaya, 2009

[5] Unicef. "Manajemen Kebersihan Menstruasi Di Sekolah". 2014. (diakses: 28 September 2018)

[6] Badan Kependudukan Dan Keluarga Berencana Nasional Direktorat Bina Ketahanan Remaja. "Pedoman
[7] Fitri, I. "Lebih Dekat dengan Sistem Reproduksi Wanita".. Yogyakarta: Gosyen Publishing, 2017.

[9] Wijayanti. "Fakta Penting Seputar Kesehatan Reproduksi Wanita". Yogyakarta: Book marks, 2009

[10] Widyaningrum, Nannyk."Pengaruh Penyuluhan Tentang Personal Hygiene Terhadap Perilaku Personal Hygiene Saat Menstruasi Di MTS Negeri Gubuk Rubuh Gunung Kidul Yogyakarta". 2015. (diakses : 26 September 2018)

[11] Notoatmodjo, S. "Promosi Kesehatan dan Ilmu Perilaku". Jakarta: Rineka Cipta, 2012

[12] Eskawati, Dwi Fitri. "Pengaruh Penyuluhan Tentang Personal Hygiene Terhadap Sikap Hygiene Saat Menstruasi Pada Siswi Kelas X SMK PGRI Bagelen Purworejo Jawa Tengah". Yogyakarta. 2010. (diakses: 14 Maret 2019

[13] Rahayu, Aminoto, Madkhan. "Efektivitas Penyuluhan Peer Group Dengan Penyuluhan Oleh Petugas Kesehatan Terhadap Tingkat Pengetahuan Tentang Menarche". Jurnal Ilmiah Kesehatan Keperawatan vol. 7. no. 2011

[14] Akhmad,Trisnawati., Kartini., Ansari Rasid. "Pengaruh Penyuluhan Personal Hygiene Terhadap Tingkat Pengetahuan Mengenai Personal Hygiene Pada Murid Kelas IV SDN Pampang Kec. Panakkukang Kota Makasar". vol. 2, no. 5. 2013 
[15] Sari, Yessy Lela. Pengaruh Penyuluhan Personal Hygiene Terhadap Pengetahuan Dan Sikap Personal Hygiene Saat Menstruasi Pada Siswi Kelas VII Di SMP Negeri 5 Karanganyar. 2017 